\title{
ON BECOMING A PASSIONATE LAWYER
}

\author{
by Pieter Carstens*
}

\section{Some reflections}

Henry David Thoreau, the American scholar-gipsy, poet, naturalist, moralist, and above all, transcendentalist, wrote the following, much quoted, passage in his famous book: ${ }^{1}$

I went to the woods because I wished to live deliberately, to front only the essential facts of life, and see if I could not learn what it had to teach, and not, when I came to die, discover that I had not lived ... I wanted to live deep and suck out all the marrow of life, to live so sturdily and Spartan-like as to put to rout all that was not life, to cut a broad swath and shave close, to drive life into a corner, and reduce it to its lowest terms, and, if it proved to be mean, why then to get the whole and genuine meanness of it, and publish its meanness to the world; or if it were sublime, to know it by experience, and be able to give a true account of it in my next excursion.

Thoreau's passionate words seem to be a logical point of departure when reflecting on the emotion of passion in context of lawyers and more specifically law students (as aspirant-lawyers). Why, one may ask, is it necessary to assess passion for the law with reference to law students? As a lecturer, however, I have come to the realisation that the hallowed halls of academia have, of late, become hollow with the apparent lack of interest in the law by many law students. Many of them have become disengaged, disinterested, and dare I say, disenchanted with the study of law. Very few 'live and study law deliberately' and certainly only the exceptional students 'suck out the marrow of the law'! Why is this so? Why has the study of law apparently become institutionalised, monotonous and, ultimately, mediocre? What has happened to the 'starry-eyed'-first year student who enrolled for law 'in the pursuit of justice and the truth', who, fuelled by an undaunted idealism, wanted to study law 'for the greater good of society'? This idealism seemingly evaporates over the years of the study of law, and many senior law students are reduced to credit-collecting, minimalist survivors who resist attendance of lectures, the research of case law and materials, lamenting about time tables, and only thriving on the memorising of previous test and

* Professor, Department of Public Law, University of Pretoria; Associate member of the Pretoria Bar.

1 HD Thoreau Walden (1854) (quoted from the 1945 edition) (WH Dircks (ed)) 88. 
examination-papers. Why, on a dramatic note, have they become so disillusioned? The answer in my opinion is simple: it is a matter of passion (or rather the lack thereof)!

The question to be posed then, is how does one rekindle the passion for law? It needs to be stated that a career in law is not primarily an exercise in the accumulation of material wealth, status and glamour! Those who make this their aim will certainly die disappointed! A successful career in law is not only dependent on a combination of knowledge, appropriate legal skills and experience, but also requires character, personality, dedication, commitment and professionalism. This is the first principle about rekindling passion for the law: know the requirements for the legal profession and then one will know what is expected - if one understands what the professional expectations are, then 'live-up' to those expectations (or at least try to cultivate them). In this regard (in context of professional expectations), much is to be gleaned from the American Bar Associations" ${ }^{2}$ identification of the ten fundamental skills and four fundamental values which every successful lawyer should possess the ten fundamental skills are: (1) problem solving; (2) legal analysis and reasoning; (3) legal research and writing; (4) fact investigation; (5) communication; (6) counselling; (7) negotiation; (8) litigation and alternative dispute resolution procedures; (9) organisation and management of legal work; (10) recognising and resolving ethical issues. The four fundamental values are: (1) providing competent representation; (2) striving to promote justice, fairness and morality; (3) striving to improve the profession; and (4) engaging in professional self-development. One would, however, be naïve to think that by simply slavishly implementing these listed skills and values on a daily basis passion for the law will follow as a matter of course. For passion to be rekindled one needs passion in itself! This is the second principle: the listed skills and values will only enhance one's professional life if these are pursued with passion; in this sense passion becomes, the elixir, as it were, for the development of these skills and values, without which the pursuit thereof becomes meaningless! While skills and values can be acquired, it needs passion, which comes from within, to propel these skills and values forward to professional articulation.

In order to know one's passion for the law, one has to discover one's passion. How is this achieved? This is the third principle: discovery of one's passion requires focus, and focus requires specialisation in law. The simple truth is that the field of law today is

'Legal education and professional development - An educational continuum' (1992), as quoted by and incorporated into CG Marnewick SC Litigation skills for South African lawyers (2007) x; for a discussion of justice and passion in historical context, compare The mediations of Marcus Aurelius trans G Long in The Harvard classics (1937) Vol $2193 \mathrm{ff}$. 
just too wide, too complex and too diverse to be a generic 'jack-ofall-trades'. The diversity in the legal field is, however, also its strength - we need legal philosophers, legal historians, tax lawyers, divorce lawyers, criminal law lawyers, human rights lawyers, constitutional lawyers, company law lawyers etc. The sooner one starts to specialise in law, the sooner one will discover one's passion for the law. As a student, one has to align oneself to that field of law or speciality which strikes at one's interest, bearing in mind one's personality, talents, hopes and aspirations. This brings one to the fourth principle: students need to understand that one will practise law as an individual and not as a collective group. People, in their quest for professional self-actualisation, traditionally enter the professions precisely because of their individual talents. One should therefore individualise one's approach to legal studies, acquiring skills and values, honing/sharpening them to perfection to set oneself apart from the collective group, realising that individuality generates and inspires passion, while the collective group, although important, tends to inhibit passion. It is individual passion that will secure success in the practice of law.

Drawing from my own experience, I was fortunate to 'discover' and 'focus' on medical law, as an elective, in my final year of undergraduate study. In hindsight, it was a life-changing encounter and three decades later I am still haunted by medical law. Medical law taught me that law is transcendental in nature and can never be an end in itself. Law only has meaning when viewed as a means. One can only assess the value and significance of law in light of how successful and effective means it proves to be in relation to a particular end. That end, hopefully, is justice within the specific context in which the law has applied. Medical law thus catapulted my young and vulnerable mind into an understanding that law begs the question of application and application begs the question of context. Immersing myself in this specialised area of law, I came to realise that the foundational principles of medical law are but facets of a larger whole, that they are not discrete and cannot be isolated from the other fields of law that link them all - comparable to a crystal lattice. In time, I came to know that like most crystals, the law is not perfect. It has its flaws, but like crystals in their natural environment, the law is capable of refinement, growth and development. It is subject to all kinds of environmental pressures and forces. It is a dynamic system. Herein lies hope for positive change and growth and the possibility of remedying the flaws that impair its purity and beauty. For law is beautiful - it has a certain elegance of logic, a certain rightness of reason, which when correctly understood and applied, is no less entrancing than the constructs of higher mathematics. ${ }^{3}$ Needless to 
say, I became infatuated with medical law - I believed that this would make me, as a lawyer, invincible and irresistible! This is the fifth principle: once one has aligned oneself to a specific speciality and focus in law, it is precisely this focus that will 'demystify' one's clogged comprehension of the rest of the seemingly tedious law curriculum. One's passion for one legal subject can thus serve as a kind of 'aversion therapy' against all those legal courses which one finds unappealing!

Once one has rekindled the passion for law, it needs to be sustained. This is the sixth principle: to sustain one's passion for the law, one has to constantly work at it - be curious; be inquisitive; be critical; be disciplined; pursue excellence; be prepared to challenge and to be challenged; read, research and above all, write about it always remember that 'reading makes a full man; conference a ready man, and writing an exact man." 4 These considerations, infused with enthusiasm and dedication, will become the driving force for one's hopes and aspirations on becoming a passionate lawyer. Above all, a passionate lawyer recognises the tradition of respectful argument. This is the seventh and last principle: the mark of a passionate lawyer is his/her ability to differ without becoming angry, sarcastic or discourteous. Such a lawyer recognises that in contingent matters there will always be a place for legitimate difference of opinion. The ability to defend one's position with spirit and conviction; to evaluate accurately the conflicting opinions of others and to retain one's confidence in the ultimate power of truth to carry its own weight, are necessary talents in any society and the essential tools of a passionate lawyer. ${ }^{5}$

Coming to the present issue of this journal at hand, I am particularly impressed and heartened by the scholarly level of the respective contributions. It is evident that the various authors are already discovering their focus and specialisation, and by implication are solidly on their way to become passionate lawyers! Those of us, who have been the strictest searchers in our quest to become passionate lawyers, will advise the present authors, that the 'sweetest marrow to be sucked out of the law' is the preserve of passionate lawyers who strive to be scholarly lawyers! It's only in the reading, the researching and the writing of the law that truth and beauty abound and living (in the words of Thoreau) indeed becomes deliberate! I rest my case, with full and complete allegiance to the closing remarks of the late, great Harry Morris QC who wrote:

4 In the words of Francis Bacon, Viscount of St Albans, English Lord Chancellor in Of Studies (1626) as quoted in Dictionary of Quotations and Proverbs (1982)(DC Browning (ed)) 22.

5 The last principle is an adaptation from JP Shannon 'The tradition of respectful argument' in RL Varco \& JP Delaney (eds) Controversy in surgery (1976) 27. See also J Munkman The technique of advocacy (1991) 4. 
Scholars! "Who", you may ask, "are the scholars?" As I near the end of my thesis and as I recall some 45 years in which my stumbling footsteps have traced the path I offer you for your journey, I feel that I can now answer that question. I am a scholar. As I write, I must think, and I must reason the why and wherefore. And if I pretend to teach, it is no more than a whimsical impertinence on my side. For in the writing and in the thinking and in the evolving of the why and the wherefore, I am teaching - teaching myself. Nor yet do I consider my lessons to have been well learned. Nor yet have I met a colleague who himself is learned beyond learning. Nor yet, least of all, can I be sure that what I advise is free of folly. I trust that I write with humility when I record that even in the greatest have I seen error. And is error anything more than a lesson yet to be learned? In every case, every consultation, every opinion, is to be found something to be learned. There is law to be learned, and foresight, and knowledge of humanity. If from these teachers you do not learn you may well fall by the wayside. May you, too, be one of the scholars. ${ }^{6}$ Technique in litigation [1969] (2010) 416. 